\title{
Caf Taht el Gar
}

\section{G. Souville}

\section{OpenEdition}

\author{
Journals
}

Édition électronique

URL : http://journals.openedition.org/encyclopedieberbere/1901

DOI : 10.4000/encyclopedieberbere.1901

ISSN : 2262-7197

\section{Éditeur}

Peeters Publishers

\section{Édition imprimée}

Date de publication : 1 septembre 1992

Pagination : 1706-1707

ISBN : 2-85744-581-4

ISSN : 1015-7344

\section{Référence électronique}

G. Souville, « Caf Taht el Gar », Encyclopédie berbère [En ligne], 11 | 1992, document C08, mis en ligne le 01 avril 2013, consulté le 10 décembre 2020. URL : http://journals.openedition.org/ encyclopedieberbere/1901; DOI : https://doi.org/10.4000/encyclopedieberbere.1901

Ce document a été généré automatiquement le 10 décembre 2020.

(c) Tous droits réservés 


\section{Caf Taht el Gar}

\section{G. Souville}

1 Grotte située à l'extrême nord-est du massif de Gorgues, près du village de Meseroha, à environ $8 \mathrm{~km}$ au sud-sud-est de Tétouan. Elle est ouverte au nord-est et domine le Rio Martin; elle est formée d'une chambre centrale d'environ $13 \mathrm{~m}$ sur 12, prolongée par deux galeries et contient des stalagmites.

2 M. Tarradell l'a fouillée en 1955 et a pu y reconnaître quatre niveaux principaux. Le plus récent contient avec des matériaux modernes, une pendeloque en calcaire et une pointe de flèche à retouches plates envahissantes qui est sans doute chalcolithique.

3 Le second niveau, partiellement remanié contient des éléments divers : hache (cassée) en pierre polie, plate à tranchant rectiligne; poinçon en os; pendeloque d'ardoise (presque rectangulaire) ; tessons de vase campaniforme (décor à bandes horizontales de lignes pointillées obliques, verticales ou horizontales séparées par des bandes lisses) ; céramique modelée lisse, noire, à éclat presque métallique avec des formes variées (bols, vases galbés, à col, en forme de calice, godets) qui est également présente à Gar Cahal et dans les niveaux inférieurs de Lixus (Tarradell M., Historia de Marruecos, Marruecospúnico, Tetuán, 1960, pp. 147-150); alêne et grand hameçon en bronze ; tessons de céramique tournée de type punique, anneau torsadé en or (pendentif (?) également punique (cf Jodin A., "Bijoux et amulettes du Maroc punique », Bull. Archéol. marocaine, t. 6, 1966, p. 56). Ces derniers objets sont à rapprocher des stations puniques très voisines, notamment celles d'Emsa et de Sidi Abdeselam del Behar (Tarradell M., Marruecos púnico, op. l, pp. 79-95). Il y a également un élément de collier en plomb.

4 Le niveau III contient de l'industrie épipaléolithique (éclats, éclats de ravivage de nucléus lamellaires, lames et lamelles brutes et retouchées, une pièce denticulée, un trapèze), deux petits poinçons en os, une pendeloque en schiste, des fragments de haches polies et une abondante céramique impressionnée, incisée, cannelée; il y a également de la céramique cardiale et de la céramique lisse.

5 De nouvelles fouilles conduites selon des méthodes modernes ont permis, depuis 1980, à J.-P. Daugas de reconnaître un niveau cardial sur plus de $150 \mathrm{~m}^{2}$ qui aurait, selon le C14, un âge de 7000 à 6000 ans. 
6 Dans le niveau IV, il n'y a que quelques silex peu typiques dont des lames et lamelles et de petits poinçons en os.

7 Les collections des fouilles Tarradell sont conservées au musée archéologique de Tétouan.

8 Cette grotte a peut-être été occupée dès l'épipaléolithique, sûrement au néolithique, au chalcolithique, au bronze et jusqu'à l'époque punique.

\section{BIBLIOGRAPHIE}

TARRADELL M., « Avance de la primera campaña de excavaciones en Caf Taht el Gar », Tamuda, Tétuán, t. 3, 1955, pp. 307-322.

Id. « Caf Taht el Gar, cueva neolitica en la région de Tetuán (Marruecos) », Ampurias, Barcelona, t. 19-20, 1957-1958, pp. 137-166.

SOUVILLE G., « La civilisation du vase campaniforme au Maroc », L'Anthropologie, t. 81, 1977, pp. 561-577.

воквот ч., Habitats et monuments funéraires du Maroc protohistorique, Aix-en-Provence, 1991, Thèse de doctorat, multigraphié.

INDEX

Mots-clés : Maroc, Préhistoire 